\title{
Effect of High-Oxygen Packaging on Respiratory Physiology and Sensorial Qualities of Fresh Shiitake Mushrooms (Lentinus edodes)
}

\author{
Yanjie $\mathrm{Li}^{1,3}$, Yutaka Ishikawa ${ }^{2}$, Takaaki Satake ${ }^{1}$, Hiroaki Kitazawa ${ }^{2} \&$ Xiaoli Qiu ${ }^{1,4}$ \\ ${ }^{1}$ Graduate School of Life and Environmental Sciences, University of Tsukuba, Tsukuba, Ibaraki, Japan \\ ${ }^{2}$ Food Packaging Laboratory, Food Engineering Division, National Food Research Institute, Tsukuba, Ibaraki, \\ Japan \\ ${ }^{3}$ School of Agricultural and Food Engineering, Shandong University of Technology, Zibo, Shandong, China \\ ${ }^{4}$ Northwest A\&F University, Yangling, Shannxi, China \\ Correspondence: Yutaka Ishikawa, Food Packaging Laboratory, Food Engineering Division, National Food \\ Research Institute, Tsukuba, Ibaraki, Japan. Tel: 81-29-838-8037. E-mail: yishi@affrc.go.jp
}

Received: April 8, 2013 Accepted: October 27, 2013 Online Published: November 8, 2013

doi:10.5539/jfr.v2n6p89 URL: http://dx.doi.org/10.5539/jfr.v2n6p89

\begin{abstract}
In this research, the effect of high-oxygen packaging (HOP) with initial $80 \%$ and $100 \%$ oxygen on fresh shiitake mushrooms was studied. Initial air in package was the control treatment. All the samples were stored at $10{ }^{\circ} \mathrm{C}$ with RH $90 \%$ for 9 days. Respiration rate, hardness, TSS, and color were determined, and sensory quality was evaluated during the storage. Results indicated that high-oxygen packaging retarded the anaerobic metabolism occurrence and HOP with initial $100 \%$ oxygen could maintain the lightness of shitake mushroom better than $80 \%$ oxygen. Hardness and TSS did not show significant difference between high-oxygen packaging and control treatment. However, neither initial $100 \% \mathrm{O}_{2}$ nor $80 \% \mathrm{O}_{2}$ could reduce the respiration rate of fresh shiitake mushroom. Sensory quality especially the aroma, cap color and gill color of fresh shiitake mushroom could be better maintained in high-oxygen packaging than control treatment. The acceptability of the shiitake mushrooms after storage was the highest in HOP with initial 100\% oxygen. In conclusion, high-oxygen packaging especially with initial $100 \%$ oxygen showed the obvious effect maintaining the sensory quality of fresh shiitake mushrooms although it could not reduce the respiration rate at $10^{\circ} \mathrm{C}$.
\end{abstract}

Keywords: high-oxygen, packaging, shiitake mushrooms, sensorial quality

\section{Introduction}

Shiitake mushroom (Lentinus edodes) is one of the most common edible mushrooms, and its cultivation and consumption have grown continuously (Ares et al., 2006; ÇaglarIrmak, 2007). Shiitake mushrooms have a high nutritional value and contain several nutritive compounds, including polysaccharides, antioxidants, dietary fiber, ergosterol, minerals, vitamin B1, B2 and C (Beluhan \& Ranogajec, 2011; ÇaglarIrmak, 2007; Jiang et al., 2010a). However, fresh shiitake mushrooms are very easy to get deteriorate and the short shelf life of mushrooms becomes an impediment to the distribution and marketing of the fresh produce (Parentelli et al., 2007; Antmann et al., 2008). Therefore, the appropriate packaging technology to preserve their quality and prolong the shelf life becomes very important.

At present, fresh shiitake mushrooms packaged in modified atmosphere packaging (MAP) are widely researched. Traditional MAP provided oxygen with low concentration or air as initial atmospheres to reduce the respiration rate of produce, but if the oxygen inside the package is consumed fast by some produce with high respiration rate, the anaerobic metabolism will be soon induced and some fermentation off-odors such as acetaldehyde and ethanol will be released. The accumulation of these off-odors formed through anaerobic respiration may have detrimental effect for storage (Francis, 1996; Oms-Oliu et al., 2008). High oxygen packaging (HOP) as an alternative to traditional MAP has been researched to be effective to reduce the anaerobic fermentation, inhibit the microbiology growth and discoloration on some fruits and vegetables. Pérez and Sanz (2001) found that when strawberries were treated by high oxygen atmospheres $\left(80 \% \mathrm{O}_{2} / 20 \% \mathrm{CO}_{2}\right.$ and $\left.90 \% \mathrm{O}_{2} / 10 \% \mathrm{CO}_{2}\right)$ and low oxygen atmosphere $\left(5 \% \mathrm{O}_{2}, 20 \% \mathrm{CO}_{2}\right)$, fungal growth could be prevented and strawberry firmness was enhanced under both high oxygen and low oxygen atmospheres, but color, titrable acidity, sugars and aroma 
were only mildly affected by high oxygen level and more affected by low oxygen atmosphere. Besides, when sliced mushrooms (Agaricus bisporus) packaged in high oxygen atmosphere, the shelf life was prolonged compared with low oxygen atmosphere. However, there are also some researches reporting that exposure to high oxygen may simulated, have no effect or reduce the respiration rate of produce depending on the commodity, maturity and ripeness stage, storage temperature and time (Jacxsens et al., 2001). Respiration rate of grapefruit was stimulated under $80 \mathrm{kPa} \mathrm{O}_{2}$ atmosphere at $14{ }^{\circ} \mathrm{C}$, however exposure of "Bartlett" pear slices to 40,60 , or 80 $\mathrm{kPa} \mathrm{O}_{2}$ decreased their respiration rates during 4 days at $10^{\circ} \mathrm{C}$ (Kader \& Ben-Yehoshua, 2000). According to the results of previous study, high-oxygen packaging with initial $100 \% \mathrm{O}_{2}$ could retard the anaerobic respiration and do less damage to the tissue membrane of fresh shiitake mushrooms, and showed the potential to maintain the nutritive compounds. However, the respiratory physiology and sensorial quality of shiitake mushrooms under high-oxygen packaging, and optimal oxygen concentration for high-oxygen packaging still call for the further research.

The objective of the study was to investigate the effect of the high oxygen packaging (HOP) with different initial oxygen concentrations on the respiratory physiology and sensorial qualities of fresh shiitake mushrooms (Lentinus edodes) during the storage.

\section{Materials and Methods}

\subsection{Samples Preparation, Packaging and Storage Conditions}

Fresh shiitake mushrooms were harvested from Ibaraki Prefecture in Japan, and transported to the lab within 24 hours of harvest. The mushrooms were stored before packaging at $10{ }^{\circ} \mathrm{C}$ with $90 \%$ relative humidity (RH) for 2 hours until the core temperature was the same as the storage chamber.

Shiitake mushrooms $(70 \pm 5 \mathrm{~g})$ were selected for uniform size and color, and packaged by Low-Density Polyethylene (LDPE) packages of $25 \mathrm{~cm} \times 15 \mathrm{~cm} \times 100 \mu \mathrm{m}$. Gas transmission rate of this film was 753.27 $\mathrm{ml} \cdot \mathrm{m}^{-2} \cdot 24 \mathrm{~h}^{-1} \cdot \mathrm{atm}^{-1}$ for $\mathrm{O}_{2}$ and $3475.54 \mathrm{ml} \cdot \mathrm{m}^{-2} \cdot 24 \mathrm{~h}^{-1} \cdot \mathrm{atm}^{-1}$ for $\mathrm{CO}_{2}$. Then different initial gases were injected into the packages after which they were heat sealed and vacuumized: (1) High oxygen packaging 1 (HOP1): $80 \% \mathrm{O}_{2}$ balanced by $\mathrm{N}_{2}$, (2) High oxygen packaging 2 (HOP2): $100 \% \mathrm{O}_{2}$, (3) Control: air. Then all the samples were stored at $10{ }^{\circ} \mathrm{C}$ with $\mathrm{RH} 90 \%$ for 9 days. Then the headspace gas composition, respiration rate, hardness, TSS concentration, color were determined, and sensory evaluation was also carried out on the day $0,2,4,7,9$.

\subsection{Gas Composition Analysis}

The headspace gas composition $\left(\mathrm{O}_{2}, \mathrm{CO}_{2}\right.$, ethanol and acetaldehyde) under all packaging conditions was measured on $0,2,4,7,9$ days of storage. $\mathrm{CO}_{2}$ and $\mathrm{O}_{2}$ concentrations in the packages were determined by withdrawing a gas sample $(1 \mathrm{ml})$ from the package headspace and injecting into gas chromatograph (GC-8A, Shimadzu, Japan) with a thermal conductivity detector (TCD) and the packed column ZY-2 consisting of Molecular Sieve 5A column, Porapak Q column and Shimalite Q column. The carrier gas was helium with 0.67 $\mathrm{ml} \cdot \mathrm{s}^{-1}$ flow rate. Column temperature was $75^{\circ} \mathrm{C}$; injector and detector temperature was $80^{\circ} \mathrm{C}$.

Ethanol and acetaldehyde concentrations were detected by injecting gas samples $(1 \mathrm{ml})$ into a gas chromatograph (GC-14B, Shimadzu, Japan) with a flame ionization detector (FID) and PEG 20M column, and the carrier gases were helium with $0.89 \mathrm{ml} \cdot \mathrm{s}^{-1}$ flow rate, hydrogen with $0.67 \mathrm{ml} \cdot \mathrm{s}^{-1}$ flow rate and air with $8.17 \mathrm{ml} \cdot \mathrm{s}^{-1}$ flow rate. Column temperature was $65^{\circ} \mathrm{C}$, injector temperature was $250^{\circ} \mathrm{C}$ and detector temperature was $275^{\circ} \mathrm{C}$.

\subsection{Respiration Rate Determination}

The respiration rate of fresh produce can be expressed as $\mathrm{O}_{2}$ consumption rate or $\mathrm{CO}_{2}$ production rate (Fonseca et al., 2002). The enclosed system was used to determine the respiration rate (Iqbal et al., 2009). In this experiment, the $\mathrm{CO}_{2}$ production rate was taken to be the respiration rate.

The vegetables were enclosed in $1 \mathrm{~L}$ airtight organic glass containers with a rubber stopper for gas sampling. Gas samples of $1 \mathrm{ml}$ were withdrawn from the container and injected into the gas chromatography (Shimadzu GC-8A, Japan) with a TCD after 0 hour, 1 hour, and 2 hours. $\mathrm{CO}_{2}$ production rate $\left(\mathrm{RCO}_{2}\right)$ was calculated as the slope of the $\mathrm{CO}_{2}$ concentration percent versus time curve shown as the equations (1) (Parentelli et al., 2007; Iqbal et al., 2009). It was expressed as $\mathrm{mg} \cdot \mathrm{kg}^{-1} \cdot \mathrm{h}^{-1}$.

$$
\mathrm{RCO}_{2}=\left(\mathrm{KCO}_{2} \times V_{f}\right) / m
$$

Where $\mathrm{RCO}_{2}$ is carbon dioxide production rate which can be expressed as $\mathrm{mg} \cdot \mathrm{kg}^{-1} \cdot \mathrm{h}^{-1}, \mathrm{KCO}_{2}$ is the slope of carbon dioxide concentration percent versus time curve which can be expressed as $\% \cdot \mathrm{h}^{-1}$. $\mathrm{V}_{\mathrm{f}}$ is the free volume of container that subtracts the sample's volume from the container volume. 


\subsection{Hardness, TSS and Color Determination}

Hardness, total soluble solids (TSS) concentration and color were measured after the 0, 2, 4, 7, 9 days of the storage. Hardness was assessed in four symmetrical places on the mushroom cap using a hardness tester (Hardmatic Type E, Mitutoyo, Kawasaki, Japan), and mean values were generated. TSS was expressed as the Brix value (\%) of the mushroom juice using a digital refractometer (PR-201 $\alpha$, Atago, Tokyo, Japan). Color determination was performed by assessing three equidistant points on the mushroom cap using a Chroma Meter (CR 300, Minolta, Osaka, Japan), and mean L* (lightness), a (red-greenness) and $\mathrm{b}^{*}$ (yellow-blueness) were generated. Three replicates were evaluated of hardness, TSS and color per day of analysis.

\subsection{Sensory Evaluation and Acceptability}

The sensory quality characteristics of shiitake mushrooms were evaluated by a panel of 5 trained assessors. The sensory quality parameters were discussed by panelists and referred to other publications and decided to score from 1 to 9 points, and scoring method could be described as: (1) Aroma, which was determined by smelling the whole mushroom, and the $9=$ full shiitake mushroom typical scent or aroma, $7=$ moderate full aroma, $5=$ moderate and slight alcohol fermentation smell, $3=$ slight aroma and obvious smelly odor, $1=$ severely and unpleasantly smelly odor. (2) Texture was determined by pressing the cap surface with fingers. $9=$ very firm and resilient, $7=$ firm, $5=$ moderately firm, $3=$ soft and less resilient, $1=$ very soft and no resilient. (3) Cap color was observed visually, $9=$ light brown, $7=$ brown, $5=$ dark brown, $3=$ dark brown with black spots, $1=$ light black. (4) Gill color was also observed gill of shiitake mushrooms visually, in which $9=$ white, $7=$ light yellow, $5=$ yellow, $3=$ dark yellow, $1=$ light brown. Then the assessors made the decision that whether they would accept the shiitake mushroom to buy or not, and the acceptability was calculated. The acceptability was calculated as percentage of the accepted samples in total samples.

\subsection{Statistical Analysis}

All the results were expressed as mean values \pm standard deviation (SD). All data were analyzed by analysis of variance (ANOVA). Differences between treatments were analyzed by LSD tests and differences at $p \leq 0.05$ were considered to be significantly different.

\section{Results and Discussion}

\subsection{Changes in Headspace Gas Composition and Respiration Rate}

Changes of $\mathrm{O}_{2}$ and $\mathrm{CO}_{2}$ concentrations in the packages were depicted in Figure 1. Both $\mathrm{O}_{2}$ and $\mathrm{CO}_{2}$ concentration changed significantly over time in all packaging conditions. $\mathrm{O}_{2}$ concentration in initial air packages decreased fast and kept $<1 \%$ from the 2 nd day of storage. Till the 4 th day, $\mathrm{O}_{2}$ concentration in initial $80 \% \mathrm{O}_{2}$ packages also decreased to lower than $1 \%$, which would induce the anaerobic metabolism. Initial $100 \%$ $\mathrm{O}_{2}$ packaging maintained the oxygen concentration $>10 \%$ till the 4 days of storage although after 7 days decreased lower than $1 \% . \mathrm{CO}_{2}$ concentration in all the high oxygen packages increased above $40 \%$ till the 4 th day and then fell down till the end of the storage. $\mathrm{CO}_{2}$ concentration in air packages increased to about $20 \%$ and then decreased mildly to the end of the storage.
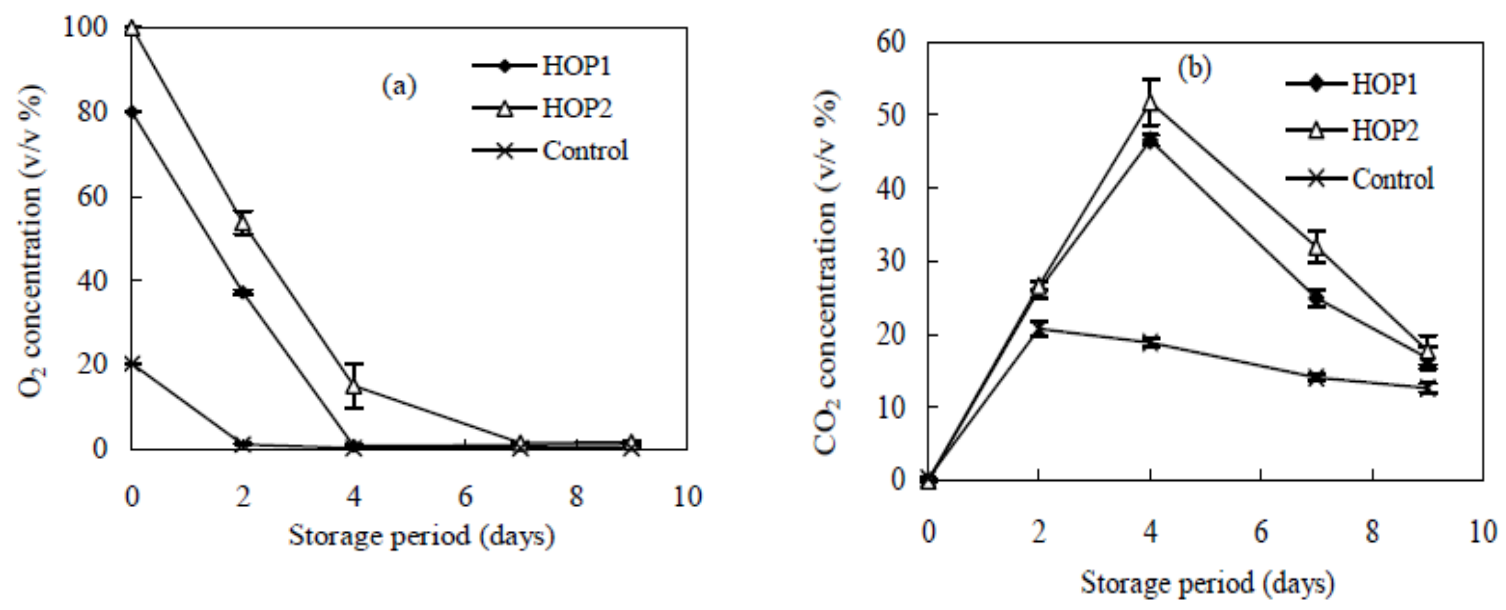

Figure 1. $\mathrm{O}_{2}$ (a) and $\mathrm{CO}_{2}$ (b) concentrations in packaged shiitake mushrooms stored at $10{ }^{\circ} \mathrm{C}$. Vertical bars represent standard deviation $(\mathrm{n}=3)$ 
Respiration rate under all the packaging conditions (showed in Figure 2) reached the climacteric peak on the second day at $10{ }^{\circ} \mathrm{C}$, after that it decreased gradually till the end of the storage. It was also obvious that the respiration rates under $80 \%$ and $100 \% \mathrm{O}_{2}$ packaging conditions were significantly higher than air conditions. It could be manifested that respiration rate of fresh shiitake mushroom could be accelerated by increasing oxygen concentration inside the package, which also induced the higher concentration of $\mathrm{CO}_{2}$ in $100 \%$ and $80 \% \mathrm{O}_{2}$ packages.

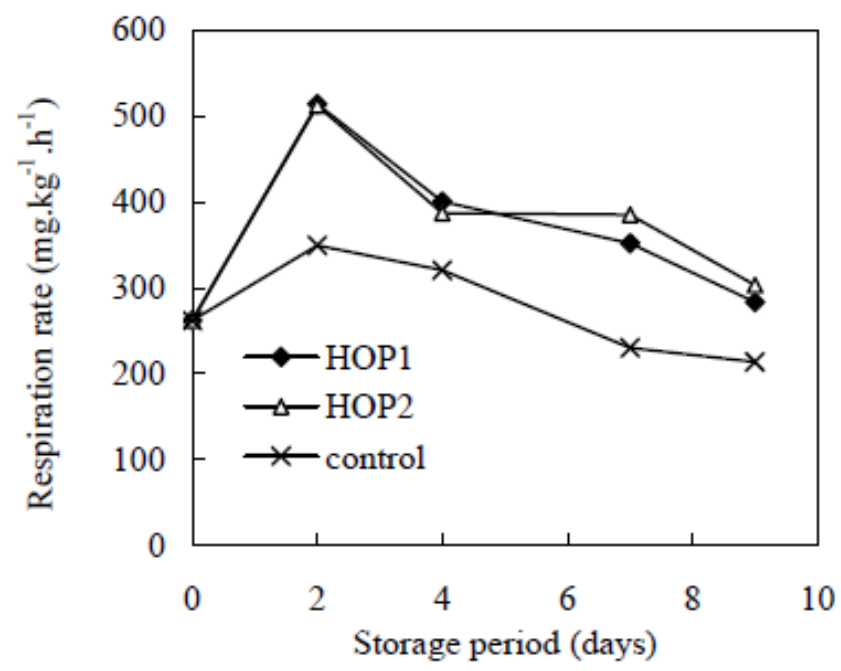

Figure 2. The changes of respiration rate of fresh shiitake mushrooms in packages with different initial oxygen concentrations
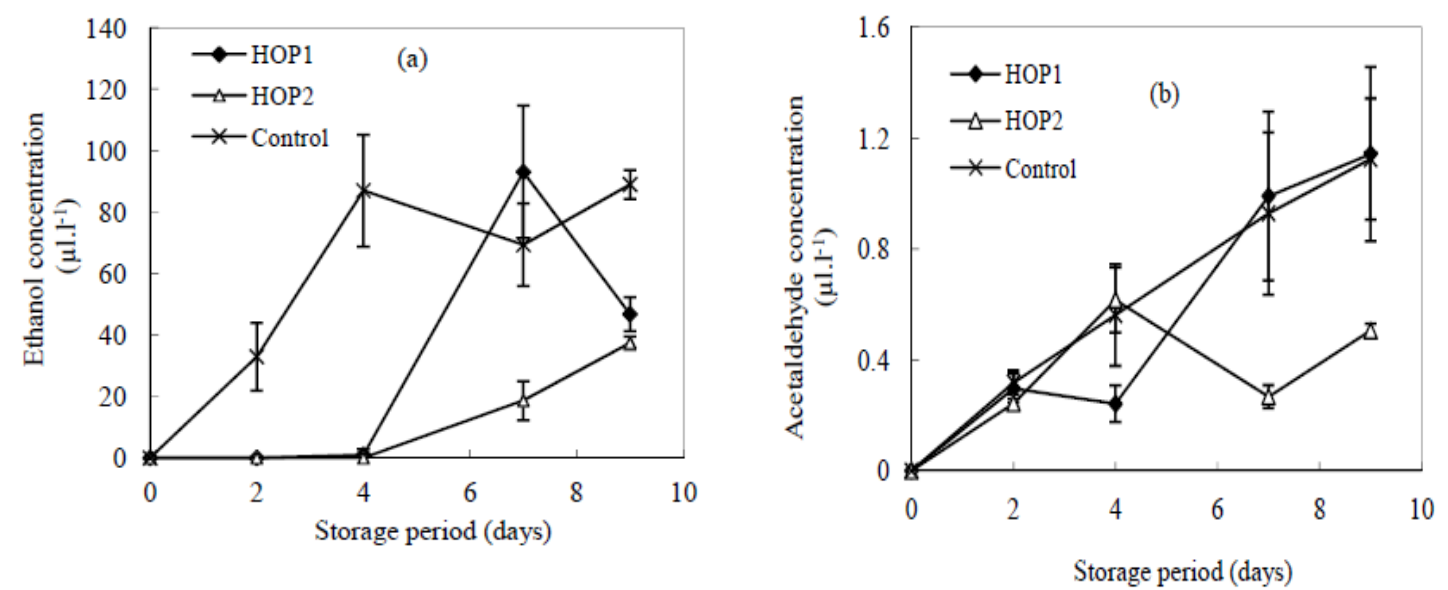

Figure 3. Ethanol and acetaldehyde concentration in packaged shiitake mushrooms stored at $10^{\circ} \mathrm{C}$. Vertical bars represent standard deviation $(\mathrm{n}=3)$. (a) Ethanol concentration, (b) Acetaldehyde concentration

Elevated $\mathrm{O}_{2}$ atmospheres may influence the production and accumulation of some volatile compounds associated with respiratory metabolism such as ethanol and acetaldehyde shown in Figure 3. Ethanol gas could be detected in all high oxygen packages after 4 days when the oxygen concentration decreased to $0 \%$, while in air packages the ethanol concentration has reached beyond $80 \mu 1 \cdot l^{-1}$ with an oxygen concentration of $0 \%$. With the storage period prolonged, ethanol and acetaldehyde concentration rose up quickly under $80 \% \mathrm{O}_{2}$ packaging and higher than air condition on Day 7, and ethanol concentration showed a decrease tendency after that. Although the fermentation off-odors could also be detected in $100 \% \mathrm{O}_{2}$ packages, the ethanol and acetaldehyde levels are much lower than $80 \% \mathrm{O}_{2}$ and air packages. Therefore low $\mathrm{O}_{2}$ atmosphere in the package could promote the production of anaerobic metabolites, and high oxygen packaging could not inhibit the fermentation metabolism 
completely, but $\mathrm{HOP}$ with initial $100 \% \mathrm{O}_{2}$ concentration reduced the ethanol and acetaldehyde concentration.

\subsection{Changes in Hardness, TSS and Color During the Storage}

Changes in hardness, total soluble solid (TSS) concentration, color parameters $\left(\mathrm{L}^{*}, \mathrm{a}^{*}\right.$ and $\left.\mathrm{b}^{*}\right)$ of fresh shiitake mushrooms under all the high oxygen and AIR packaging conditions at $10^{\circ} \mathrm{C}$ throughout 9 days' storage were depicted in Table 1. Samples under all the three packaging conditions decreased in hardness during the storage, but did not have any significant difference between treatments. Until the Day 9, hardness of the HOP1 and HOP2 samples were higher than control samples although there was not any significant difference. This result was different with the high oxygen packaging applied on strawberries which showed that HOP exhibited lower hardness compared to low $\mathrm{O}_{2}$ MA (Van der Steen et al., 2002). TSS content of shiitake mushrooms did not show any obvious change during the storage at $10{ }^{\circ} \mathrm{C}$, and the different packaging conditions also did not contribute any advantages for TSS content. Colors in all the color parameters did not change dramatically until the 4 days of storage, but on the Day 7, significant higher $\mathrm{L}^{*}$ was observed in HOP1, and significant higher a ${ }^{*}$ value was observed in both HOP1 and HOP2. At the end of the storage, hardness, TSS content, $\mathrm{L}^{*}$ and $\mathrm{b}^{*}$ values in high oxygen packaging were higher than AIR packaging, which manifested that high oxygen packaging could prevent the browning better than AIR packaging.

Table 1. Changes of hardness, TSS and color $\left(\mathrm{L}^{*}, \mathrm{a}^{*}\right.$ and $\left.\mathrm{b}^{*}\right)$ in packaged shiitake mushrooms

\begin{tabular}{|c|c|c|c|c|c|}
\hline & Hardness (N) & TSS (\%) & $\mathrm{L}^{*}$ & $a^{*}$ & $\mathrm{~b}^{*}$ \\
\hline Initial & $14.78 \pm 1.65$ & $2.28 \pm 0.43$ & $42.54 \pm 1.86$ & $12.68 \pm 0.32$ & $28.55 \pm 2.06$ \\
\hline \multicolumn{6}{|l|}{ Day 2} \\
\hline $\mathrm{HOP} 1\left(80 \% \mathrm{O}_{2}\right)$ & $14.03 \pm 3.89^{\mathrm{a}}$ & $1.78 \pm 0.21^{\mathrm{a}}$ & $38.32 \pm 2.98^{\mathrm{a}}$ & $12.11 \pm 0.72^{\mathrm{a}}$ & $22.65 \pm 2.26^{\mathrm{a}}$ \\
\hline $\mathrm{HOP} 2\left(100 \% \mathrm{O}_{2}\right)$ & $19.70 \pm 6.81^{\mathrm{a}}$ & $2.03 \pm 0.24^{\mathrm{a}}$ & $39.91 \pm 5.78^{\mathrm{a}}$ & $12.32 \pm 0.99^{\mathrm{a}}$ & $23.33 \pm 2.31^{\text {a }}$ \\
\hline Control(Air) & $14.03 \pm 2.93^{\mathrm{a}}$ & $1.95 \pm 0.65^{\mathrm{a}}$ & $41.20 \pm 5.25^{\mathrm{a}}$ & $12.33 \pm 1.39^{\mathrm{a}}$ & $24.73 \pm 1.62^{\mathrm{a}}$ \\
\hline \multicolumn{6}{|l|}{ Day 4} \\
\hline $\mathrm{HOP} 1\left(80 \% \mathrm{O}_{2}\right)$ & $11.63 \pm 4.01^{\mathrm{a}}$ & $1.70 \pm 0.29^{\mathrm{a}}$ & $42.68 \pm 2.63^{\mathrm{a}}$ & $12.30 \pm 0.43^{\mathrm{a}}$ & $25.39 \pm 1.77^{\mathrm{a}}$ \\
\hline $\mathrm{HOP} 2\left(100 \% \mathrm{O}_{2}\right)$ & $12.03 \pm 3.92^{\mathrm{a}}$ & $1.58 \pm 0.41^{\mathrm{a}}$ & $36.59 \pm 9.80^{\mathrm{a}}$ & $12.09 \pm 0.64^{\mathrm{a}}$ & $20.23 \pm 5.95^{\mathrm{a}}$ \\
\hline Control (Air) & $14.58 \pm 5.42^{\mathrm{a}}$ & $1.93 \pm 0.40^{\mathrm{a}}$ & $41.98 \pm 8.63^{\mathrm{a}}$ & $11.65 \pm 0.31^{\mathrm{a}}$ & $26.20 \pm 6.00^{\mathrm{a}}$ \\
\hline \multicolumn{6}{|l|}{ Day 7} \\
\hline $\mathrm{HOP} 1\left(80 \% \mathrm{O}_{2}\right)$ & $10.00 \pm 2.87^{\mathrm{a}}$ & $3.00 \pm 0.47^{\mathrm{a}}$ & $46.60 \pm 5.49^{\mathrm{a}}$ & $10.59 \pm 2.04^{\mathrm{ab}}$ & $28.71 \pm 5.08^{\mathrm{a}}$ \\
\hline $\mathrm{HOP} 2\left(100 \% \mathrm{O}_{2}\right)$ & $7.58 \pm 4.18^{\mathrm{a}}$ & $2.20 \pm 0.27^{\mathrm{a}}$ & $35.06 \pm 3.02^{\mathrm{b}}$ & $13.36 \pm 0.72^{\mathrm{a}}$ & $23.38 \pm 3.28^{\mathrm{a}}$ \\
\hline Control (Air) & $9.63 \pm 3.37^{\mathrm{a}}$ & $2.55 \pm 0.75^{\mathrm{a}}$ & $39.99 \pm 2.59^{\mathrm{b}}$ & $12.13 \pm 0.98^{\mathrm{b}}$ & $26.41 \pm 2.21^{\mathrm{a}}$ \\
\hline \multicolumn{6}{|l|}{ Day 9} \\
\hline $\mathrm{HOP} 1\left(80 \% \mathrm{O}_{2}\right)$ & $9.18 \pm 2.28^{\mathrm{a}}$ & $2.98 \pm 0.13^{\mathrm{a}}$ & $45.73 \pm 3.72^{\mathrm{a}}$ & $11.32 \pm 1.18^{\mathrm{a}}$ & $30.16 \pm 2.84^{\mathrm{a}}$ \\
\hline HOP2 $\left(100 \% \mathrm{O}_{2}\right)$ & $7.38 \pm 3.42^{\mathrm{a}}$ & $2.90 \pm 0.41^{\mathrm{a}}$ & $43.09 \pm 5.09^{\mathrm{ab}}$ & $11.76 \pm 0.72^{\mathrm{a}}$ & $27.32 \pm 3.13^{\mathrm{ab}}$ \\
\hline Control (Air) & $7.15 \pm 1.38^{\mathrm{a}}$ & $3.05 \pm 0.26^{\mathrm{a}}$ & $37.87 \pm 2.17^{b}$ & $10.72 \pm 0.98^{\mathrm{a}}$ & $24.23 \pm 2.55^{\mathrm{b}}$ \\
\hline
\end{tabular}

Storage temperature: $10^{\circ} \mathrm{C}$.

All the results were expressed as mean values \pm standard deviation (SD).

Mean values with different letters are significantly different $(n=3, p \leq 0.05)$.

\subsection{Changes in Sensorial Quality and Acceptability}

Sensorial quality of shiitake mushrooms stored at $10{ }^{\circ} \mathrm{C}$ was determined during the storage. On the second day, aroma under all the HOP conditions was significant higher than that under AIR condition. HOP with $100 \% \mathrm{O}_{2}$ concentration initially showed higher values in texture, cap color and gill color than other packages after 2 days of storage, but didn't show any significant difference. From the Day 4 to Day 9, aroma scores for mushroom under AIR condition decreased significantly compared with other packaging conditions. However, texture scores under air condition were higher than other conditions and showed significant difference compared with $100 \% \mathrm{O}_{2}$ condition. There were not obvious changes in cap color and gill color during the whole storage period, and significant differences cannot be detected between all the packaging conditions. Therefore, the result indicated that high oxygen packaging could maintain the aroma of fresh shiitake mushrooms, but could not keep the texture better compared with the air atmosphere. 
Acceptability has a highest correlation $\left(\mathrm{R}^{2}=0.66\right)$ with aroma among the four sensory parameters. Acceptability kept stable $100 \%$ in all high oxygen packages till the 4 days of storage. But about $50 \%$ samples were rejected from the 2nd day under air packaging condition. After 4 days, more samples could not be accepted and $0 \%$ acceptability was showed up in AIR condition, but about $50 \%$ in HOP till the end of the storage. Therefore, the in-package atmosphere of air accelerated the decreasing rate of acceptability of shiitake mushrooms and decreased their shelf life, when compared to mushrooms packaged under high oxygen condition during the 9 days' storage period.

Table 2. Sensory scores of packaged fresh shiitake mushrooms

\begin{tabular}{|c|c|c|c|c|}
\hline & Aroma & Texture & Cap color & Gill color \\
\hline Initial & $8.77 \pm 0.20$ & $8.22 \pm 0.19$ & $7.44 \pm 0.51$ & $7.22 \pm 1.92$ \\
\hline \multicolumn{5}{|l|}{ Day 2} \\
\hline $\mathrm{HOP} 1\left(80 \% \mathrm{O}_{2}\right)$ & $8.00 \pm 1.15^{\mathrm{a}}$ & $7.25 \pm 0.96^{\mathrm{a}}$ & $7.00 \pm 0.00^{\mathrm{a}}$ & $6.50 \pm 1.29^{\mathrm{a}}$ \\
\hline $\mathrm{HOP} 2\left(100 \% \mathrm{O}_{2}\right)$ & $8.00 \pm 1.15^{\mathrm{a}}$ & $8.00 \pm 1.15^{\mathrm{a}}$ & $7.50 \pm 1.00^{\mathrm{a}}$ & $7.50 \pm 1.00^{\mathrm{a}}$ \\
\hline Control(Air) & $2.50 \pm 1.00^{\mathrm{b}}$ & $7.50 \pm 1.00^{\mathrm{a}}$ & $6.50 \pm 1.00^{\mathrm{a}}$ & $7.50 \pm 1.00^{\mathrm{a}}$ \\
\hline \multicolumn{5}{|l|}{ Day 4} \\
\hline $\mathrm{HOP} 1\left(80 \% \mathrm{O}_{2}\right)$ & $7.50 \pm 1.00^{\mathrm{a}}$ & $6.50 \pm 1.00^{\mathrm{a}}$ & $6.50 \pm 1.00^{\mathrm{a}}$ & $6.00 \pm 1.15^{\mathrm{a}}$ \\
\hline $\mathrm{HOP} 2\left(100 \% \mathrm{O}_{2}\right)$ & $7.00 \pm 0.00^{\mathrm{a}}$ & $6.50 \pm 1.00^{\mathrm{a}}$ & $6.00 \pm 1.15^{\mathrm{a}}$ & $6.50 \pm 1.00^{\mathrm{a}}$ \\
\hline Control (Air) & $2.50 \pm 1.91^{\mathrm{b}}$ & $7.00 \pm 1.63^{\mathrm{a}}$ & $6.00 \pm 1.15^{\mathrm{a}}$ & $7.25 \pm 0.50^{\mathrm{a}}$ \\
\hline \multicolumn{5}{|l|}{ Day 7} \\
\hline $\mathrm{HOP} 1\left(80 \% \mathrm{O}_{2}\right)$ & $4.50 \pm 1.00^{\mathrm{a}}$ & $4.50 \pm 1.91^{\mathrm{a}}$ & $6.00 \pm 1.15^{\mathrm{a}}$ & $6.00 \pm 1.15^{\mathrm{a}}$ \\
\hline $\mathrm{HOP} 2\left(100 \% \mathrm{O}_{2}\right)$ & $3.50 \pm 1.00^{\mathrm{ab}}$ & $4.50 \pm 1.00^{\mathrm{a}}$ & $5.00 \pm 0.00^{\mathrm{a}}$ & $6.50 \pm 1.00^{\mathrm{a}}$ \\
\hline Control (Air) & $2.50 \pm 1.91^{\mathrm{b}}$ & $6.00 \pm 1.15^{\mathrm{a}}$ & $6.00 \pm 1.15^{\mathrm{a}}$ & $6.50 \pm 1.00^{\mathrm{a}}$ \\
\hline \multicolumn{5}{|l|}{ Day 9} \\
\hline $\mathrm{HOP} 1\left(80 \% \mathrm{O}_{2}\right)$ & $2.00 \pm 1.15^{\mathrm{ab}}$ & $4.50 \pm 1.00^{\mathrm{ab}}$ & $6.00 \pm 1.15^{\mathrm{a}}$ & $6.00 \pm 1.15^{\mathrm{a}}$ \\
\hline HOP2 $\left(100 \% \mathrm{O}_{2}\right)$ & $3.00 \pm 1.63^{\mathrm{a}}$ & $3.50 \pm 1.00^{\mathrm{b}}$ & $5.00 \pm 0.00^{\mathrm{a}}$ & $6.00 \pm 1.00^{\mathrm{a}}$ \\
\hline Control (Air) & $1.00 \pm 0.00^{\mathrm{b}}$ & $5.00 \pm 0.00^{\mathrm{a}}$ & $5.50 \pm 1.00^{\mathrm{a}}$ & $5.50 \pm 1.00^{\mathrm{a}}$ \\
\hline
\end{tabular}

Storage temperature: $10^{\circ} \mathrm{C}$.

All the results were expressed as mean values \pm standard deviation (SD).

Mean values with different letters are significantly different $(n=3, p \leq 0.05)$.

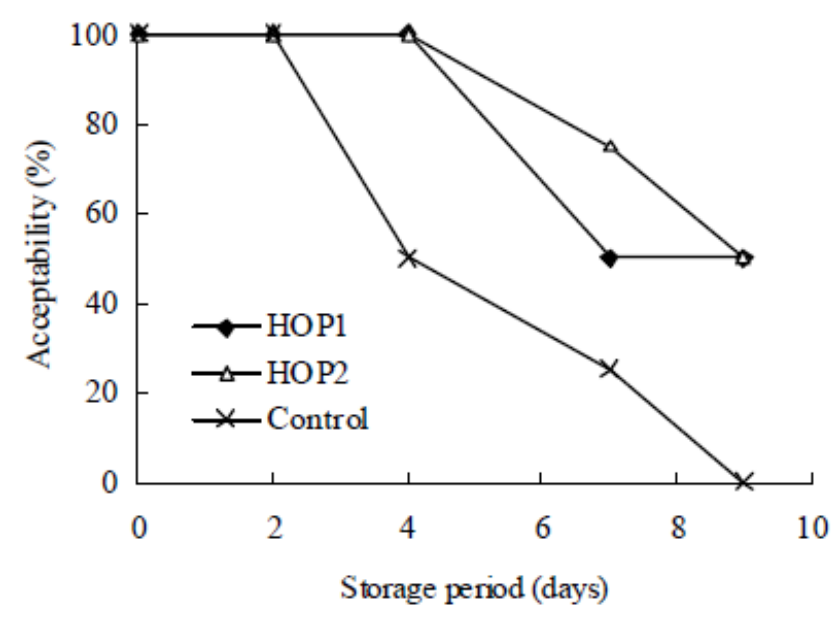

Figure 4. Acceptability of packaged shiitake mushrooms stored at $10{ }^{\circ} \mathrm{C}$ 

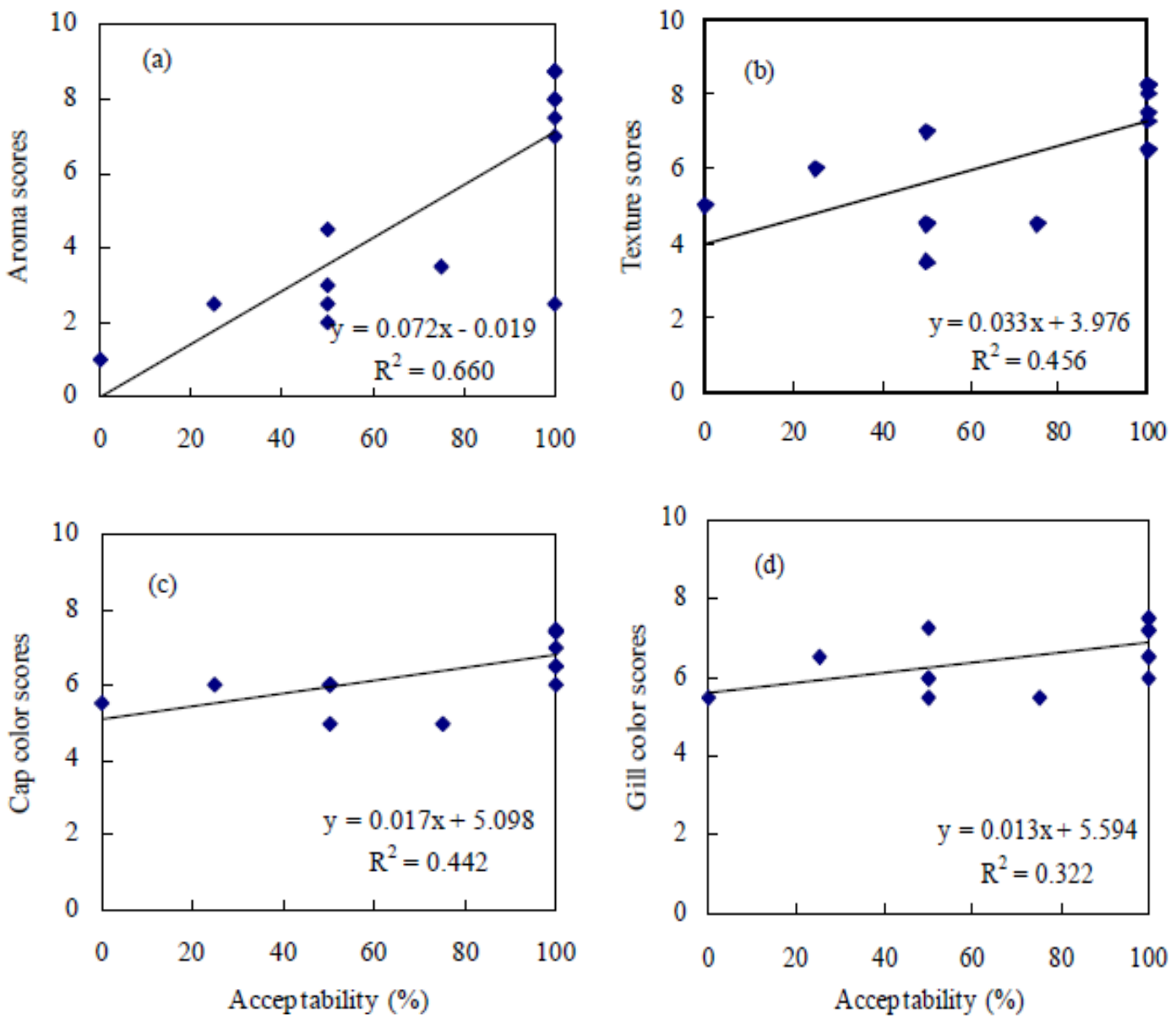

Figure 5. Correlation $\left(\mathrm{R}^{2}\right)$ between acceptability and sensory parameters

(a) Aroma, (b) Texture, (c)Cap color, (d) Gill color.

\section{Conclusion}

High oxygen packaging with initial $100 \% \mathrm{O}_{2}$ and $80 \% \mathrm{O}_{2}$ had beneficial effect on the sensorial quality of fresh shiitake mushrooms by retarding the anaerobic metabolism occurrence and contributing the better aroma scores compared with air packaging. HOP could not reduce the respiration rate or prevent the fermentation metabolism of shiitake mushrooms completely, but HOP with initial $100 \% \mathrm{O}_{2}$ could retard the ethanol and acetaldehyde accumulation. Mushroom's hardness, color parameters of $\mathrm{L}^{*}$ and a $\mathrm{a}^{*}$ got significant higher values in HOP than in air packaging after the storage, but TSS content did not show any significant difference between treatments. Aroma played an important role when judging the sensorial quality of fresh shiitake mushrooms, and aroma scores in HOP samples were significantly higher than AIR samples. During the storage, samples stored under HOP condition especially $100 \% \mathrm{O}_{2}$ atmosphere, showed a lower deterioration rate and higher sensory quality than those stored under air condition.

\section{References}

Antmann, G., Ares, G., Lema, P., \& Lareo, C. (2008). Influence of modified atmosphere packaging on sensory quality of shiitake mushrooms. Postharvest Biology and Technology, 49, 164-170. http://dx.doi.org/10.1016/j.postharvbio.2008.01.020

Ares, G., Parentelli, C., Gámbaro, A., Lareo, C., \& Lema, P. (2006). Sensory shelf life of shiitake mushrooms stored under passive modified atmosphere. Postharvest Biology and Technology, 41, 191-197. http://dx.doi.org/10.1016/j.postharvbio.2006.03.013

Beluhan, S., \& Ranogajec, A. (2011). Chemical composition and non-volatile components of Croatian wild edible mushrooms. Food Chemistry, 124, 1076-1082. http://dx.doi.org/10.1016/j.foodchem.2010.07.081 
ÇaglarIrmak, N. (2007). The nutrients of exotic mushrooms (Lentinula edodes and Pleurotus species) and an estimated approach to the volatile compounds. Food Chemistry, 105, 1188-1194. $\mathrm{http}: / / \mathrm{dx}$.doi.org/10.1016/j.foodchem.2007.02.021

Fonseca, S. C., Oliveira, F. A. R., Frias, J. M., Brecht, J. K., \& Chau, K. V. (2002). Modelling respiration rate of shredded Galega kale for development of modified atmosphere packaging. Journal of Food Engineering, 54, 299-307. http://dx.doi.org/10.1016/S0260-8774(01)00216-3

Francis, M, M. (1996). Regulation of respiratory metabolism in fruits and vegetables by carbon dioxide. Postharvest Biology and Technology, 9, 247-264. http://dx.doi.org/10.1016/S0925-5214(96)00019-1

Iqbal, T., Rodrigues, F. A. S., Mahajan, P. V., \& Kerry, J. P. (2009). Mathematical modelling of $\mathrm{O}_{2}$ consumption and $\mathrm{CO}_{2}$ production rates of whole mushrooms accounting for the effect of temperature and gas composition. International Journal of Food Science \& Technology, 44, 1408-1414. http://dx.doi.org/10.1111/j.1365-2621.2009.01971.x

Jacxsens, L., Devlieghere, F., Van der Steen, C., \& Debevere, J. (2001). Effect of high oxygen modified atmosphere packaging on microbial growth and sensorial qualities of fresh-cut produce. International Journal of Food Microbiology, 71, 197-210. http://dx.doi.org/10.1016/S0168-1605(01)00616-X

Jiang, T., Luo, S., Chen, Q., Shen, L., \& Ying, T. (2010a). Effect of integrated application of gamma irradiation and modified atmosphere packaging on physicochemical and microbiological properties of shiitake $\begin{array}{lllll}\text { mushroom } \quad \text { (Lentinus } & \text { Fododes). }\end{array}$ http://dx.doi.org/10.1016/j.foodchem.2010.03.050

Kader, A. A., \& Ben-Yehoshua, S. (2000). Effects of superatmospheric oxygen levels on postharvest physiology and quality of fresh fruits and vegetables. Postharvest Biology and Technology, 20, 1-13. http://dx.doi.org/10.1016/S0925-5214(00)00122-8

Oms-Oliu, G., Soliva-Fortuny, R., \& Martín-Belloso, O. (2008). Physiological and microbiological changes in fresh-cut pears stored in high oxygen active packages compared with low oxygen active and passive modified atmosphere packaging. Postharvest Biology and Technology, 48, 295-301. http://dx.doi.org/10.1016/j.postharvbio.2007.10.002

Parentelli, C., Ares, G., Corona, M., Lareo, C., Gámbaro, A., Soubes, M., \& Lema, P. (2007). Sensory and microbiological quality of shiitake mushrooms in modified-atmosphere packages. Journal of the Science of Food and Agriculture, 87, 1645-1652. http://dx.doi.org/10.1016/j.postharvbio.2008.01.020

Pérez, A. G., \& Sanz, C. (2001). Effect of high-oxygen and high-carbon-dioxide atmospheres on strawberry flavor and other quality traits. Journal of Agricultural and Food Chemistry, 49, 2370-2375. http://dx.doi.org/10.1021/jf0014381

Van der Steen, C., Jacxsens, L., Devlieghere, F., \& Debevere, J. (2002). Combining high oxygen atmospheres with low oxygen modified atmosphere packaging to improve the keeping quality of strawberries and $\begin{array}{lllll}\text { raspberries. Postharvest Biology and } & \text { Technology, } & \text { 26, } & \text { 49-58. }\end{array}$ http://dx.doi.org/10.1016/S0925-5214(02)00005-4

\section{Copyrights}

Copyright for this article is retained by the author(s), with first publication rights granted to the journal.

This is an open-access article distributed under the terms and conditions of the Creative Commons Attribution license (http://creativecommons.org/licenses/by/3.0/). 